\title{
Corporate Philanthropy Through the Lens of Ethical Subjectivity
}

\author{
Claudia Eger $^{1}$ ([) $\cdot$ Graham Miller $^{2} \cdot$ Caroline Scarles $^{2}$
}

Received: 5 October 2016/Accepted: 13 April 2017/Published online: 28 April 2017

(c) The Author(s) 2017. This article is an open access publication

\begin{abstract}
The dynamic organisational processes in businesses dilute the boundaries between the individual, organisational, and societal drivers of corporate philanthropy. This creates a complex framework in which charitable project selection occurs. Using the example of European tour operators, this study investigates the mechanisms through which companies invest in charitable projects in overseas destinations. Inextricably linked to this is the increasing contestation by local communities as to how they are able to engage effectively with tourism in order to realise the benefits tourism development can bring. This research furthers such debates by exploring the processes through which tour operators facilitate community development through charitable giving. Findings show, with no formal frameworks in existence, project selection depends upon emergent strategies that connect the professional with the personal, with trust being positioned as a central driver of these informal processes. Discretionary responsibilities are reworked through business leaders' commitment to responsible business practises and the ethical subjectivity guiding these processes.
\end{abstract}

Keywords Corporate philanthropic selection processes . Ethical subjectivity $\cdot$ Stakeholder engagement and trust

Claudia Eger

c.eger@warwick.ac.uk

1 Faculty of Social Sciences, University of Warwick, Coventry CV4 7AL, UK

2 Faculty of Arts and Social Sciences, University of Surrey, Guildford GU2 7XH, UK

\section{Introduction}

There exists a general belief that ethical business cultures contribute to good long-term business prospects in which discretionary activities can build positive moral capital (Besser et al. 2006; Duarte 2010; Godfrey 2005). This is well reflected by corporations' investment in philanthropic projects, which establish a connection between the top of the pyramid of corporate social responsibility and wider stakeholder interests (Carroll and Shabana 2010; Ismail 2009). However, philanthropy's discretionary nature reflects the potential partiality of philanthropic investments that can raise moral and political concerns in the selection of causes and beneficiaries (Barnett and Land 2007; Chin et al. 2013; Wang et al. 2015). This can lead to a polarisation of communities through the wealth distribution processes and the multiplier effects entailed within these processes. Pressures of globalisation, technological advancements and ever-increasing global economic fragility further compound the urgency of this, contributing to an increasing detachment of businesses from individual communities. In this context, the "encouragement of relationship development and community development through corporate giving becomes an even more important project in the advancement of sustainable corporate societies" (Saiia et al. 2003, p. 187).

The complexity, uncertainty and often serendipitous nature of philanthropic engagements call for a better understanding of the ethical frameworks underpinning the enactment of corporate responsibility. While there is an increasing body of literature on the role of managers' values on firms' CSR performance, there is limited knowledge on the different channels through which their values are transformed in the decision-making process (Le et al. 2015). A rational approach to studying managerial 
choice prevails, with a responsible decision on ethical issues often being equated to the application of universal or a priori defined rules and obligations (Baïada-Hirèche et al. 2011). This, however, limits the ability to conceive of business ethics as "a practice of choice and evaluation" (Clegg et al. 2007a, p. 111) where the moral role of corporations is exercised through the actions of business leaders (see Greenwood and Van Buren III 2010).

In the dynamic field of everyday management practise, decisions are taken in an imperfect environment (Weaver et al. 1999), where intuitive beliefs and affective capacities often precede ethical reasoning (Haidt 2001; Sonenshein 2007). This contrasts with the normative perspective of stakeholder theory, which requires corporations to "acknowledge the validity of diverse stakeholder interests" and "attempt to respond to them within a mutually supportive framework" (Donaldson and Preston 1995, p. 87). Rather, stakeholder claims are predominantly addressed through the informal operating system (Falkenberg and Herremans 1995), with trust representing a significant mediator in this process (Pirson and Malhotra 2011). The interrelationship between businesses and their stakeholders in the charitable realm is not well understood, particularly with regard to the connection between stakeholders and managerial discretion and the extent to which firms' charitable involvement contributes to social outcomes, such as community welfare (Halme and Laurila 2009; Love and Higgins 2007).

This research explores philanthropic selection processes and the role of stakeholders within that, using the context of tour operators' philanthropic engagement in the Education for All (EfA) project in Morocco. EfA is a tourism-supported educational project established in 2007, which provides boarding houses for girls from remote villages to facilitate their access to the state schooling-system. The research adopts a practise-based approach to ethics, which is premised on a relational conception of subjectivity "circumscribed by organisational rules, norms and discourses" (Clegg et al. 2007a, p. 107). This provides a link between individual values and feelings of moral responsibility and the organisation's position towards ethics (Ibarra-Colado et al. 2006), further taking into consideration how these relations and positions are reworked through stakeholder engagement. This acknowledges the social embeddedness of ethics in which business practise is continuously unfolding as a context-driven performance based on mutual interdependence and trust (Thorne and Saunders 2002; Wicks et al. 1999). Adopting this approach provides greater depth and understanding of the dynamic interplay of stakeholders and organisations and the ways in which managers actually choose the projects and communities they want to engage with.
Building on limited existing research on decision-making processes in philanthropic engagement (Gautier and Pache 2015; Wang et al. 2015), this study provides original contributions to three main areas. The first area of contribution expands current knowledge of the formation and influence of ethical subjectivity on charitable selection processes providing insights to the mechanisms through which companies invest in charitable projects in overseas destinations. Philanthropic choices entail a mix of purposive, informal and subjective practises, whose complexity cannot be surmised simply as unplanned philanthropic decision-making process. This study investigates the complexity of these dynamics within the realm of improvised action, intuition and trust, following Clegg et al.'s (2007a) approach to business ethics as practise. The second contribution arises through the exploration of the role that stakeholders play in selection processes, to "address the possibility of stakeholders as catalysts for increasing levels of discretion" (Phillips et al. 2010, p. 177). Managerial discretion, however, also reflects the aforementioned partiality of philanthropic investments, which links with the increasing contestation by local communities as to how they are able to realise the benefits development can bring. The third area of contribution draws attention to the processes through which corporations facilitate community development critiquing the role of access to, and voice in, philanthropic selection processes.

In order to present the key original contributions, the paper is structured as follows. First, the literature review examines corporate philanthropic choices through the lens of ethical subjectivity and reflects on the contributions of such an approach to understanding business ethics as practise. Secondly, the methodology guiding this research is presented. Thirdly, findings on tour operators' charitable project selection within the key areas of corporate social consciousness, intuitive decision-making and improvisation as well as trust and stakeholder engagement are discussed. Lastly, conclusions are offered alongside the limitations of this research and an indication of potential avenues for future research.

\section{Philanthropic Decisions Through the Lens of Ethical Subjectivity}

The decision over the allocation of resources for different causes and beneficiaries often lies with top management (Brammer et al. 2006), with recent scholarship suggesting that business leaders' individual social consciousness is the main driver of corporate (philanthropic) decision-making (see e.g. Duarte 2010; Ibarra-Colado et al. 2006; Wang et al. 2015). Managers' "personal value system and concept of morality develops a background for identifying and 
evaluating the ethicality of business decisions" (Gavai 2010 , p. 6), which corresponds with the argument that executives' values are key in strategy processes (Elms et al. 2010; Phillips et al. 2010). Social responsibilities are tied to company strategy or interest, delineating the interplay between individual, organisational and contextual factors in managerial choice (Hambrick 2007). In particular, charitable project selection which is often not regulated by company policy, nor directly expected by society (Carroll 1991; see also Carroll and Shabana 2010), "leaves substantial room for managerial discretion in determining what social problems and issues are relevant and how they should be addressed" (Wood 1991, p. 698).

\section{Motivations: Co-implication of Altruism and Self- interest}

Motivations for supporting corporate philanthropy are described along a continuum ranging from altruistic to strategic motives (Hemingway and Maclagan 2004; Saiia et al. 2003). Business leaders' values play a crucial role in this process, particularly in organisational fields that emphasise economic value sets over stakeholder values (Le et al. 2015). On an individual level, an important reason for donating money for people is often to feel better or good about themselves (Bekkers and Wiepking 2011). Managers' inclination to engage in philanthropy, hence, might consciously or unconsciously be driven by the individual expectation of deriving personal satisfaction from "doing good". The "co-implication of self-interest and altruism" can be described as forming the basis of ethical subjectivity (Barnett and Land 2007, p. 1071). The individual dynamics driving this behaviour have been associated with a "joy of giving" (see Ribar and Wilhelm 2002), which emphasises the embodied experience of giving, with not only the expectations, but also the potential drivers of this behaviour being rooted in people's feelings and emotions.

This form of responsible behaviour, rather than being a reflection of altruistic intention, is often related to the model of enlightened self-interest (Hallak et al. 2013). The rationale is that companies' investment in the community can improve corporate performance (Besser et al. 2006), with community goodwill representing a key effect of corporate philanthropy (Hallak et al. 2013). Social investments in philanthropic projects that benefit the wider community can improve the competitive context in which companies operate (Porter and Kramer 2002). This "enables a company not only to give money, but also to leverage its capabilities and relationships in support of charitable causes" (Porter and Kramer 2002, p. 6). This is consistent with the description of philanthropy as a strategic tool "a manager has for improving profits, instilling customer loyalty, enhancing employee morale, and building community relations" (Buchholtz et al. 1999, p. 167). However, this approach does not take into account the morality of choice processes, with "many or most of the norms that seem to constrain rationality [being] moral norms" (Elms et al. 2010, p. 408).

\section{Business Ethics as Practise}

Authors are increasingly referring to the role of morality and doubt in choice processes (Clegg et al. 2007a, b; Elms et al. 2010), which questions a movement towards strategic philanthropy (Saiia et al. 2003). Morality is described as the capacity to decide between "good" and "bad" or "better" and "worse" actions and it is the undecidabilitythe allowing of doubt in selection processes, which reflects the moral element of choice (Clegg et al. 2007b). Selection processes, hence, are compounded by the ambiguity and subjectivity accompanying philanthropic engagements, where the outcomes for both, companies and stakeholders, are often uncertain (Halme and Laurila 2009; Lee et al. 2009). This elevates the role of critical practise in business ethics (Weiskopf and Willmott 2013), which acknowledges the complexity and at time controversial nature of corporate philanthropy.

Managerial responsibility entails an intertwined contextspecific process of interpretation and practise, which is consistent with the definition of "ethics as the social organising of morality" (Clegg et al. 2007a, p. 111). However, "traditional business ethics studies largely overlook some significant 'hidden mechanisms" (BaïadaHirèche et al. 2011, p. 30) reflecting the difficulty of capturing subjectivity in day-to-day management practise. Ethical subjectivity entails a "process of becoming" (Loacker and Muhr 2009, p. 268), which is characterised by heterogeneous practises. Stakeholders play an important role in this process through their influence on managerial discretion and expected behaviour (see Phillips et al. 2010). This study identifies intuition and trust as core modalities of action in (philanthropic) choice processes, providing novel insights to the formation of ethical subjectivity in practise-based approaches to business ethics.

\section{Intuition and Ethical Judgements}

Normative discussions of business ethics often do not acknowledge the intuitive underpinning of ethical judgements (Baïada-Hirèche et al. 2011; Sonenshein 2007; Tenbrunsel and Smith-Crowe 2008). Individuals, however, employ two cognitive processes in their decision-making processes, reasoning and intuition, which draw on explicit and implicit theories. Moral reasoning is often a post hoc process to justify the "right" choice, in which individuals apply ethical theories and norms to their a priori choices 
(Haidt 2001). Intuitions, on the other hand, are "affectively charged judgements that arise through rapid, non-conscious, and holistic association" (Dane and Pratt 2007, p. 40). These rapid intuitive forms of moral judgement include an affective valence, which can be positive or negative (see Sonenshein 2007) and does not rely on scrutinising evidence. Instead, this is "a process akin to aesthetic judgement: One sees or hears about a social event [or philanthropic project] and one instantly feels approval or disapproval" (Haidt 2001, p. 818).

Managers' intuitive appraisal of situations can support them in making unconscious fast judgements that are guided by intuition-as-expertise and, or intuition-as-feeling (Sadler-Smith and Shefy 2004, p. 81). The latter provides a realm for emotions, which, based on the social intuitionist model of Haidt (2001), has a stronger relationship with moral action than reasoning. Individuals often rely on their intuitions before engaging in ex post facto reasoning, with intuitions forming part of their sensemaking devices. However, moral intuitions are also based on interpersonal processes and shaped by social norms or pressures, with the latter being consistent with the influence that business policy can have on managerial behaviour (see Gavai 2010).

Individuals also use their intuitions in trust-related judgements (Kramer 2006), with the increasing reliance on intuition, trust and emotions being termed "in between strategies" by Zinn (2008). These are aimed at "complementing and overcoming some of the limitations of instrumental and calculative forms of risk and uncertainty management" (Zinn 2008, p. 439). However, rather than being "in between" strategies, these practises form part of daily management practise, although they are partly implicit and not observable.

\section{Trusting Expectations as Selection Mechanism}

The relevance of trust in organisational settings has long been recognised, for example, in relation to trustworthiness (Greenwood and Van Buren III 2010), leadership (Dirks and Ferrin 2002), and inter-organisational relationships (Schilke and Cook 2013), but its catalytic role in corporate philanthropic decision-making has received limited attention.

Trust is a multi-layered construct that can be issued on multiple levels and between different entities, with possible "trust transfer" occurring between these (Schilke and Cook 2013, p. 289). Relationships of trust can bear significant weight in choice processes, as they help to decrease the complexity associated with uncertain situations (Luhmann 1979). Trust is often perceived as an effect (Rousseau et al. 1998), but in relation to decision-making it can function as an enabling mechanism building on the interpersonal process entailed in moral choice. It is a mechanism that continually "re-establishes" itself, potentially strengthening over time, if the other party complies with the expectations of the trusting party, or turning into distrust if the foundations of trust are not maintained. Optimal trust in organisational settings, hence, also contains an element of distrust (Wicks et al. 1999), which acknowledges the entailed risks and vulnerabilities on both sides (see Mayer et al. 1995).

\section{(Moral) Values and Trust Creation}

Managers' values can "help determine levels of trust in relationships between the firm and its various stakeholders" (Wicks et al. 1999, p. 99; see also Le et al. 2015). Simultaneously, the reliance on trust and intuition can mobilise these values, amplifying managerial discretion in the process. In organisational theory, trust is predominantly conceptualised based on the expectations guiding relationships (Hosmer 1995), with managers' reliance on trust in philanthropic selection allowing them to increase their latitude of decision-making through incorporating stakeholders in this process. Expectations here are not necessarily guided by anticipated outcomes of projects, with most firms not expecting any direct returns from their social investments (Maas and Liket 2011). Rather, these expectations are formed through relying on the foundations of trust by assessing the trusted party's ability, integrity, and benevolence, i.e., their trustworthiness (Mayer et al. 1995; see also Pirson and Malhotra 2011).

The reliance on the moral intentions and motives of the other party alludes to the implicit moral duty in definitions of trust as moral exchange (Greenwood and Van Buren III 2010; Hosmer 1995). This is largely based on a subjective belief in moral character, which emphasises responsiveness and answerability. These interpersonal constructs acknowledge the role of voice in expressing values and shared meanings, with the "silencing of voice [being] the key barrier to taking ethical action" (Edwards and Kirkham 2014, p. 483). This leaves moral doubt concerning which stakeholders are in the position to enter the sphere of influence and negotiations of choice that form part of the "process of becoming" underpinning ethical subjectivity.

This section discussed companies' motivations to invest in corporate philanthropy, with the scale of operations and the networks established between organisations and stakeholders shaping their approaches to, and practises of, corporate philanthropy. Directors and managers play a key role in these processes, with their value and belief system being negotiated through their commitment to business values and strategic concerns. Still, a form of ethical subjectivity prevails that is marked by the convergence of altruistic and self-interested motives and finds expression in the reliance on trust, emotion, and intuition in selection 
processes. Next, the methodology guiding this study is presented.

\section{Methodology}

The methodology is based on an interpretivist approach, which is concerned with attaining an insider-centred perspective to research (Punch 2013). The meanings attached to social actions form part of the dynamic relation of the "ideas actors hold, the inter-subjective discourses and traditions on which they draw in developing such ideas, and, crucially, the institutional and extra-discursive context in which those ideas and traditions come to acquire and retain resonance" (Hay 2011, p. 168). In this study, the wider context encompasses the physical and non-physical presences of tour operators in destination communities through their support of a wide web of charitable projects, which raises questions about the value of tourism and its ethical conduct as an industry.

The research strategy is based on an embedded case study (see Yin 2009), which is positioned within the context of tour operators' involvement in destination communities, identifying the Education for All (EfA) project in Morocco as the main case. The research is based on up to six months fieldwork in the High Atlas Mountains of Morocco conducting participant observation and qualitative interviews in the EfA project and the surrounding Berber communities. These methods capture the personal perspectives, feelings, and often tacit elements underpinning decision-making processes, with reflexivity in the research process being assured through maintaining a field diary (see Coffey 1999). Such an approach provides insights to the complexities and the power relations forming part of business-stakeholder negotiations, with Pirson and Malhotra (2011) and Müller et al. (2014) highlighting the need for context-specific studies of trust in organisational research.

The findings presented form part of a larger study investigating capacity building and empowerment processes in the EfA project and the effects thereof on community development. However, they are not independent of the larger study, with the EfA project being the main focus of the overarching study. As the goal is not generalisability, but to explore managerial selection practises, a purposive sampling strategy was adopted (see Saunders et al. 2012). Criteria for selection of respondents were based on their involvement in, or knowledge of, the EfA project, with tourism actors being identified on the basis of their participation in charitable selection processes.

The research is informed by 63 community member interviews and 11 tour operator related interviews. Three tour operators participated in this study and while they had head offices based in a range of European countries, commonality existed as all of those selected supported the EfA project and all tours were Western-induced and oriented. Five in-depth qualitative interviews were conducted with senior management and a product development manager, with repeat interviews being conducted as required. In addition, four EfA staff members, one groundhandling agent, and a community leader were interviewed as part of the tour operator related interviews. These stakeholders directly informed tour operators' selection processes and/or were involved in the management of philanthropic projects.

A qualitative semi-structured approach to interviewing was adopted to allow for the co-construction of knowledge and to encourage personal reflection (Bryman 2008; Longhurst 2010). Similar approaches to studying corporate responsibility have been used by Duarte (2010) and Perrini and Minoja (2008). During the interviews responsible business practises underpinning the selection of, and engagement in, philanthropic projects were discussed, with issues of trust emerging as implicit within these. Relevant community projects were identified to explore the reasons for and process of choosing specific charitable initiatives. The degree of involvement of local stakeholders in identifying opportunities was addressed, together with the importance of these projects for wider community development. In addition, longer-term strategies for continuing or withdrawing support were discussed. These central points of conversation built the basis around which interviews developed, with respondents actively shaping the interview process through their answers, which allowed exploring emerging topics.

The analysis of data followed the three-staged thematic analysis approach of King and Horrocks (2010), adding a fourth level of data familiarisation (see Braun and Clarke 2006). To ensure the anonymity of research participants, all interview data were anonymised. Tour operator (TO) respondents are identified by their position as director or manager and by number (e.g. TO1, TO2), with related tourism actors being identified by their role as agent, community leader, or EfA staff. Community members are identified by pseudonym. The analysis was conducted using NVivo 10, to support the organisation of the large amount of data and the iterative coding process, which included data familiarisation, descriptive coding, thematic coding with a final identification of overarching patterns (see King and Horrocks 2010). The researchers further relied upon a continuous process of peer debriefing to reflect and critically analyse the interpretation of findings, which contributed to the clarification and finalisation of the thematic structure. Attention now turns to the main themes that emerged in the analysis of charitable selection processes. 


\section{Practising Ethical Subjectivity}

Recent discussions emphasise the role of ethical issues in tourism development (see e.g. Coles et al. 2013; Hallak et al. 2013), with tourism's ability to "emerge and remain an agent of good will" being influenced by the capacity of involved actors to make "ethically sound decisions" (Fennell and Przeclawski 2003, p. 140). Tour operators' increasing charitable engagement forms part of their responsible business practises, with their work drawing together a spatially diverse web of stakeholders. However, no universal mechanism or methodology exists for tour operators to adopt when selecting the projects and communities that they choose to engage with.

In tourism we always meet new people [...] new ideas $[\ldots]$ sometimes when we are hiking with a group we talk about the work of the association and voluntary engagement and they tell us they [want to] help. (Ali)

Tour operators' portfolio of projects can vary widely in the number and in the type of projects they support, which range from environmental to social and education-related projects. For example, TO1 manages a portfolio of over 100 projects, incorporating these into their tours and providing direct financial support to 15 of the projects. A basic continuum of project selection was identified ranging from an informal to a formal approach. Tour operators' formality of investigation depends on the scale of the planned investment and on the degree of trust in the other party. The formality is higher, if the project's concept will be applied to a whole range of tours and/or across customers and ground-handling agents. In this case, more formal selection criteria are applied and more time is spent on researching the particular project. However, if the project will only affect a small number of tours, informal criteria predominate, which build strongly on intuition and trust relations. Independently, if the tour operator trusts the counterpart, this also decreases the level of investigation prior to selecting a project.

[...] if it's a small project that applies to one or two tours $[. .$.$] each year that is going to be fairly quick. But$ if it's something that we think can be rolled out to most our African or actually its concept across to all our customers, to all our ground agents that is certainly worthwhile [...] a lot more time. (Director, TO1)

The following sections are structured around the main themes that emerged in the analysis: corporate social consciousness, intuition and improvisation, as well as, trust and stakeholder engagement. Key findings are summarised in Table 1 highlighting the formation and influence of ethical subjectivity on philanthropic selection processes. The table further provides additional illustrative examples that support the key contributions of this study.

\section{Corporate Social Consciousness}

All tour operators in this study conceptualise philanthropy as the need to either "give back" or "help out", due to established relationships with communities through which businesses thrive. This is consistent with a wider stakeholder perspective based on the interdependent web of relationships in which tourism businesses are able to operate. "It is putting something back into the communities that we travel through that is the most appropriate way" (Director, TO1). Tour operators engage in different mechanisms for, and forms of, "giving back", with the former including the reliance on trust, improvisation and intuition and the latter financial or in-kind support, time commitment, technical skills and managerial expertise.

\section{Altruistic Intention to Give Back}

Respondents emphasised that they are not gaining any direct benefits from supporting the projects; instead their main motivation to donate money is to benefit the projects. "[W]e only hope that the project will benefit $[\ldots]$ but it is absolutely not that it is benefitting us. [...] It is just for helping out that is the main reason" (Director, TO2). Reflecting upon this and work by Du et al. (2013), this reaffirms the importance of altruistic intentions as a motivating factor in decision-making processes.

Du et al. (2013) identify individual social consciousness as a key determinant of firms charitable giving, with altruistic reasons being more prevalent than business reasons for this behaviour. This confers an increased latitude of decisionmaking to the director of the firm, who takes the final decision over which projects are going to be supported. "[E]verything in that respect you have to get [name of director] to sign off" (Manager, TO1), with his or her values becoming key determinants in the choice process. This is consistent with a form of individual social consciousness, which can actively drive collective corporate social consciousness. These findings are also supported by recent scholarly work, which highlights the importance of leadership style and commitment on CSR engagement (Duarte 2010; Hemingway and Maclagan 2004; Le et al. 2015).

While elevating the individual level could foster the pursuit of individual altruistic intentions as opposed to those of the firm (Arulampalam and Stoneham 1995), some of the respondents' companies have won awards for social engagement. These companies position themselves as responsible tour operators in the market partly through the 
Table 1 Formation and influence of ethical subjectivity on philanthropic selection processes Source: Own elaboration

\begin{tabular}{lll}
\hline Formation of Ethical Subjectivity & $\begin{array}{l}\text { Influence of Ethical Subjectivity on } \\
\text { Philanthropic Selection Processes }\end{array}$ & Illustrative Examples
\end{tabular}

Corporate Social Consciousness

Concept of morality based on wider stakeholder perspective to "give back" to communities.

Doubt, as the moral element of choice, requires attention to (moral) silences, politics and multiple subjectivities forming part of ethical subjectivity.

Intuition and Improvisation

The enactment of ethical frameworks relies on the same set of skills employed in day-today management practise.

Intuition as core determinant of moral action informs tacitly the "process of becoming" underpinning ethical subjectivity.

\section{Trust and Stakeholder Engagement}

Trust enters the moral realm of firm relations through expectations of ethical behaviour.

Trust in business-stakeholder relations is a geographical practise inscribed in space, which requires increased sensitivity to potential differences in professional and moral norms.
Motivations to engage in corporate philanthropy influence the subsequent development of relationships of mutual benefit and trust.

Co-implication of altruism and enlightened self-interest: Altruistic intentions rooted in personal value system act as motivating factor and are re-negotiated through strategic business concerns.

Individual social consciousness drives corporate social consciousness, with the articulation of values and choice in selection processes being mobilised through trust and intuition.

Improvisation allows flexibility in the selection process and scope for adaptation to new market trends; however, having no clear guidelines can lead to systematic problems in project selection.

Intuitions are expressed through affective (moral) judgements and personal beliefs/convictions. Aesthetic judgements of "what looks good" can, however, lead to an instrumental approach to philanthropy.

Emotional responses foster the development of corporate affiliations, which are, in turn, mobilised through trust.

Trust, as implicit human quality, is the main informal selection criteria. This implies variable degrees and kinds of risk to firms and stakeholders.

Stakeholder engagement amplifies managerial latitude of decision-making, with trust becoming a proxy for mitigating uncertainty, complexity and unobservable outcomes.

Trust shifts responsibility in selection processes to dominant stakeholders. Power imbalances can lead to a denial of access and voice of (dependent) stakeholders in negotiations.
[I]t is not one of our aims that we are always looking for projects [...] the people behind it that is the core business for us. (Director, TO2)

$[F]$ or us to find good projects that would not only benefit the local community, but also obviously we are a business and we want our customers to have a good time. (Manager, TO1)

[W]e just went in winter to Ait Bougemas valley and bought some food for the boarding school [...] because our directors were originally from the area. (Agent)

It is really just ad hoc projects; someone comes along and says, would you like to do this [...] So we do not really have a specific strategy for that. (Manager, TO1)

Lots of the things we do here, I look at it [...] I can see that it is good and I could try and spend time and effort to get numbers of certain things, but that is a waste of time [...] we have an idea and we do it. (Director, TO1)

We more do it for what we think feels right. (Manager, TO1)

I think the people behind it they must be involved [...] that is the main thing. [...] I know they are very good and I am trusting the people behind the organisation. (Director, TO2)

If it is something new on the ground, which our tour leaders might think it is interesting to go to, then that will be the way to do it. (Director, TO1)

No one asks for poor people. The association has a lot of help from associations in Europe [...] but they do not give anything, any help to the poor people. (Ahmed) philanthropic projects they support. "[W]e talk about responsible tourism as in that sort of [charitable] projects [...] we do" (Manager, TO1). Through this positioning they have become accountable to their customers and employees to operate their business responsibly.

\section{Enlightened Self-interest: License to Operate}

Particularly in tourism, caring for the needs of the community can be understood as a "license to operate"
(Goodwin 2011), which was emphasised through the need to be "responsible for everything that we will be welcomed back to community" (Director, TO1). However, "good projects" were not only described as projects that would benefit the community, but also as projects that would provide a good experience for customers: "For me that is the Holy Grail to find worthwhile projects for them to be interesting for our customers, we are tour operators having tours after all" (Director, TO1). A women's association member commented "when tourists come to buy some of 
the products we also go with them to the house to show them the way of live of people in the village" (Lamia).

These embodied encounters with host communities on the tour enrich customer experience (Jamal and Menzel 2009), while providing tourists arguably with more insights to the operational processes accompanying the performance of responsibility. This indicates that to a certain degree tour operators' philanthropic giving is inspired by their expectation to be seen as responsible tour operators, to secure a loyal customer base and to attract new customers. This elevates the business value of corporate philanthropy as part of companies' CSR agenda. However, it does not capture the multifaceted operationalisation of responsible practise within the tourism industry, which is underpinned by power relations and the ethical subjectivities guiding this approach.

\section{Intuition and Improvisation}

Respondents' ad hoc approach to project selection can be described as improvised with no overt strategic plan guiding the process. "It's just by accident, by meeting people, by hearing about things and that is how it works" (Director, TO2). This is similar to findings from other studies, such as that by Briedenhann (2011), reporting on a limited strategic approach to philanthropy. The groundhandling agent further highlighted how this characterises subsequent project engagement: "It's all about finding out while you go along whether it's working or not" (Agent). A community member confirmed this tactic of trial and error. "The organisations from tourism that come to give help $[\ldots]$ they give the associations first time and second time, if there is a change they will continue to help, if not they will stop" (Jalal).

Time constraints were raised as one of the main factors limiting respondents' ability to search for projects in a more focused way, with time constraints also influencing the (in)formality tour operators adopt in selection processes. "You can only allocate so much time on these things and sometimes you have to make quite quick decisions, or decisions without perfect knowledge, but then that is what I do all the time" (Director, TO1). The quote suggests that philanthropic decision-making requires the same set of skills employed in day-to-day management practise, i.e., dealing with imperfect knowledge.

This is consistent with a dynamic approach to charitable project selection (and engagement), where available choices are mediated by personal values, intuition and trust. Tour operators approach to project identification as "something that you meet on the way and that you think, well-let's do it!" (Director, TO2) provides scope for the adaptation to new market trends, but it could also lead to systematic problems, as worthy, but non-articulated causes may not find their way into tour operators' choice set.

\section{Intuition as Aesthetic Judgement}

The intuitive process is intertwined with an aestheticised approach to project selection, illustrated through the metaphor of a gardener, where flowers represent the projects supported by tour operators.

I also take what I call the approach of a gardener. I do not know anything about flowers, but I look in my garden and I love it and it looks nice and I am very happy with my garden. And sometimes I plant a few more plants and sometime they look good and sometimes they are bad. But, I do not study it, I do not reassure it, I just look at it. (Director, TO1)

The experiential process of intuiting becomes apparent, where the gardener can see, if his or her decision has been "right" depending on, whether the flowers look good. Yet, it also expresses a sense of detachment from the garden, as it is not central to the welfare of the house (business), or integral to the well-being of the observer. This emphasises the peripheral positioning of philanthropy; "it's not our business" (Director, TO2). Tour operators in this study had limited awareness about projects' potential internal outcomes, i.e., the gardener who has no knowledge about flowers. For instance, the reasons for investing in projects situated in rural areas were tied to projects' heightened visibility, which suggests that tour operators and related stakeholders are aware about the potential external outcomes of projects, for example enhancing reputation and customer experience.

[W]e prefer places, more remote, less access [...] In the towns, even if you go visit and contribute, it does not appear, while in the small areas [...] you can see the project building and next year you can come back again with the group and say we sponsored this. (Agent)

While this can lead to an instrumental approach to responsible business practise, the responses were mainly driven by "intuition-as-feeling". This alludes to the "joy of giving", where the individual feels happy about his or her garden. This is consistent with the importance of taking into consideration how different projects engender affect and emotions through forms of corporeal and aesthetic charisma, as elaborated by Lorimer (2007) in relation to conservation projects.

A guide from Agarsioval [...] works in an agency in Marrakesh and when this school [student fieldtrip] asked this man that they wanted to help some 
villages; he said that 'my village needs help' and he brings them here. (Lamia)

Emotional responses can be based on personal preferences, interests or ties, as illustrated in the previous quotation and can in turn drive organisational affiliation. "We do that, because we feel that it is something worth supporting in a particular area" (Director, TO1). Tour operators' sense of affiliation is reflected through the mostly long-term support they provide to projects, which has facilitated the emergence of a shared understanding based on past experience; "if you look at the volume of business, you can see that [name of hotel] on a very regular basis is one of our favourite accommodations" and people behind the EfA "are the same trustworthy people" (Director, TO2). These affiliations are often mobilised through the reliance on trust, which facilitates the selection of, and engagement in, philanthropic activities.

\section{Trust and Stakeholder Engagement}

The dispersed geographical scale on which tour operators conduct their business, does often not allow for a locally situated approach to philanthropy. This requires an increasing attention to the role that stakeholders play in negotiations of tourism-related projects. Tour operators' philanthropic choices are often based on trust relationships, which emphasise a transformational leadership approach based on stakeholder engagement, commitment as well as affective capacities. Trust is the main informal criterion guiding the selection of charitable projects. "[I]t's always the people behind [the philanthropic projects] that bring us to participate" (Director, TO2). This selection criterion is not necessarily based on the kind of project and, or its focus. Rather, it is the recognition of trust as a form of implicit human quality that tour operators in this study often base their selection on, with trust also playing a key role in the subsequent engagement or disengagement with projects. Trust enters the moral realm of business relations through its emphasis on expectations of ethical behaviour, particularly under conditions of missing social and corporate controls. It takes a central role in ensuring ethical obligations are met, with the assumed integrity and benevolence of the other party serving as a measure to gauge uncertainty levels. "I think it just depends on how much they were putting into it, their integrity" (Manager, TO1). This conceptualisation of integrity relates to a subjective belief in moral character, which can be underpinned by the recognition of shared corporate values leading to an "expectation of a similar behavior" (Hosmer 1995, p. 399). The ground-handling agent, for example, identifies that part of his business philosophy is "to spread the benefit of tourism to everyone, not to monopolise" (Agent). This argument concurs with the responsible business model of the participating tour operators in this study. Local partners are often considered to be experts in their field and represent an important point of reference for tour operators devising initiatives to fund in destination communities. Trust in the other party's ability or competence influences the identification of local needs as well as the subsequent selection of philanthropic projects.

Especially, if there is someone we trust as in Morocco, we really trust our local agent there, so if they come to us and tell us that area needs a lot of help $[\ldots]$ and that is how you can help. (Manager, TO1)

The reliance on trust shifts responsibility in project selection to dominant stakeholders, such as local elites, who posses power and legitimacy, while it may deny access to dependent stakeholders (see Mitchell et al. 1997). This approach, hence, might not lead to equitable access to, and distribution of benefits, while potentially silencing some forms of knowledge in the process.

\section{Access and Voice: Whose Choice?}

Many authors have noted the prevalence of elites in controlling development processes at the local scale (Tucker and Boonabaana 2012; Wall and Norris 2003), with Aref et al. (2010) identifying local leadership as key constraint to equitable project engagement. This also serves to distance peripheral neighbourhoods from strategic conversations, as noted by a tour guide in this study: "There is no relationship between tourism and the local association" (Ali). Tourism benefits are mostly ascribed to the centre of Imlil; "those who are in Imlil live from tourism" (Jumanah). In remote communities "tourism does not add anything to the village, because they just come here and make a turn and go back, no development" (Yasmine). While it can be argued that the EfA project benefits remote villages through providing access to school for girls from these villages, an uncritical approach to project selection and charitable donations still conceals potential power differentials in bargaining positions, as exemplified below.

They have a problem with the community leader, because he only wants to help his region - Imlil, where he and the people from his family are from. Only they benefit from the projects [...] They give the right for participation just to people they want. (Personal communication, community member)

Other community members raised the predominant absence of women from strategic conversations; "women have no roles in tourism [...] just men" (Mustafa), which illustrates that some voices are silenced in negotiation processes. 
The [association] members don't like to help the women to change the situation. [...] There are some tourism actors that come and give help to the entire village, but there is no one who knows what the association does with this help. (Zineb)

The barriers to participation in strategic tour operator negotiations, hence, are associated with kinship ties, community hierarchies, and cultural norms. This requires an increased attention not only to the motives for charitable giving, but also to the processes underpinning responsible action and the politics governing the places in which these projects are realised. Trust can be an enabling factor in developing stakeholder relations that play a catalytic role in managerial choice processes. However, it is also an intrinsically geographical practise inscribed in spaces in which professional and moral norms differ. This might challenge the role of trust as the basis of, and potential mechanism to, providing mutual benefits.

\section{Conclusion}

The practise-based approach to business ethics adopted in this study allows capturing the "hidden" mechanisms driving philanthropic decision-making processes, showing that the constitution of moral values and motives in this process is inherently linked with the subjective realm providing a connection between the personal and the professional.

This study supports the findings of Du et al. (2013), Maak and Pless (2006) and Perrini and Minoja (2008) reporting on the significant role of directors and managers in shaping the pro-social behaviour of firms. Respondents expressed an altruistic impulse, which was underpinned by the individual's embodied experience of giving rooted in personal values and feelings. Tour operators' altruistic intentions are further re-negotiated through the strategic concerns of the company, which were mainly associated with enhancing customer experience, brand reputation and community goodwill. The co-implication of altruism and (enlightened) self-interest in selection processes is consistent with the conception of ethical subjectivity by Barnett and Land (2007), though it extends this further by showing that the articulation of values and choice is mobilised through trust and intuition. Through these practises the enactment of ethical frameworks becomes inherently linked with the skills employed in day-to-day management practise. This re-emphasises the importance of understanding the strategic level of philanthropy, including tour operators' approach to selecting their charitable acts.

This research finds that tour operators' selection of projects does not follow formal frameworks. Rather, it becomes embedded within a complex mix of dedicated action, informal advice, and serendipitous opportunity. While tour operators' capacity as a functioning organisation does not always allow them to realise the values they have, or realise them to their most optimum capacity, it is crucial to note that their informality is also based on intuitive beliefs and personal conviction, such as that expressed in the "gardener approach". This study finds that intuition is a core determinant of moral action, informing tacitly the "process of becoming" underpinning ethical subjectivity. Intuitive decision-making corresponds with the aesthetic judgement of projects and the different ways in which projects engender affect. This, in turn, can drive organisational commitment to particular causes and the development of a sense of affiliation through best practise and continued engagement in projects. These affiliations were mobilised through the reliance on trust facilitating the selection of, and engagement in, philanthropic activities.

Trust was identified as one of the main informal criterion guiding tour operators' selection of projects, with managers and directors' trust in the other party's trustworthiness allowing them to amplify their latitude of decision-making. Trust functions not only as mechanism for project selection, but also as the foundation for the development of long-term project relationships. Companies' trusting expectations defer a sense of responsibility to project leaders or trusted parties, rather than expecting specific outcomes of projects. This finding contributes to the conceptualisation of doubt as the moral element of choice (see Clegg et al. 2007a, b) highlighting that doubt in decision-making processes can be resolved on an interpersonal level, in which trust becomes a proxy for mitigating uncertainty, complexity and unobservable outcomes. Through this process, trust enters the moral realm of philanthropy providing a nexus between moral expectations, stakeholder engagement and issues of power. This, however, implies variable degrees and kinds of risk to the reputation of tour operators and to dependent stakeholders, which requires acknowledging the power imbalances accompanying charitable selection processes.

\section{Research Limitations and Future Research}

This research provides a platform of understanding for future research in this area; such research could provide a more in-depth study of the interconnection between the enactment of ethical frameworks and managerial discretion, and the role of intuition within that. This study finds that both trust and intuition can function as enabling mechanisms in selection processes. However, more work remains to be done to explore the processes through which intuition can amplify managerial discretion in decisionmaking, for example, by identifying specific managerial 
values that correlate with the reliance on intuitive judgements, and exploring the mediating role that organisational factors, such as company size, play in this process. Alongside this, instruments need to be developed that capture these often tacit and unobservable intuitive processes.

There is further a growing interest in the role of trust in tourism development (see e.g. Moscardo 2014; Nunkoo and Smith 2014) with this research contributing to this body of literature by shedding light on the role of trust in connecting different actors and drawing multiple levels of responsible action together. However, the sample of this study makes it difficult to draw general recommendations from the research and due to the exploratory nature of this research some of the concepts discussed have received limited attention. While findings indicate that trust could play a significant role in advancing business ethics, many questions remain with regard to the ethical values that are professed through, and underlining the reliance on trust in the corporate realm. An emphasis on trust at the task level of analysis could provide insights to whether and when trust enters organisational processes, further offering insights to the connection between trust and the enactment of ethical values. This indicates the need for the development of theoretical frameworks that address how moral judgements are actually made in day-to-day management practise.

A full understanding of the role of intuition and trust in moral judgements, alongside the prevalent focus on reasoning, is key to advance moral action in businesses and to develop policies that foster enabling environments. This study further calls for an extension of the role of moral doubt in selection processes to consider the moral silences, multiple subjectivities and politics traversing narratives of philanthropy, and the negotiation thereof.

Funding This study was funded by the Economic and Social Research Council (Grant Number 1223594).

\section{Compliance with Ethical Standards}

Conflict of interest Claudia Eger has received a research grant from the Economic and Social Research Council and non-financial support from Explore Worldwide. Graham Miller and Caroline Scarles declare that they have no conflict of interest.

Ethical Approval All procedures performed in studies involving human participants were in accordance with the ethical standards of the institutional and/or national research committee and with the 1964 Helsinki Declaration and its later amendments or comparable ethical standards. This article does not contain any studies with animals performed by any of the authors.

Informed Consent Informed consent was obtained from all individual participants included in the study.
Open Access This article is distributed under the terms of the Creative Commons Attribution 4.0 International License (http://crea tivecommons.org/licenses/by/4.0/), which permits unrestricted use, distribution, and reproduction in any medium, provided you give appropriate credit to the original author(s) and the source, provide a link to the Creative Commons license, and indicate if changes were made.

\section{References}

Aref, F., Redzuan, M., Gill, S. S., \& Aref, A. (2010). Assessing the level of community capacity building in tourism development in local communities. Journal of Sustainable Development, 3(1), 81-90.

Arulampalam, W., \& Stoneham, P. (1995). An investigation into the givings by large corporate donors to U.K. charities, 1979-1986. Applied Economics, 27, 935-945.

Baïada-Hirèche, L., Pasquero, J., \& Chanlat, J. F. (2011). Managerial responsibility as negotiated order: A social construction perspective. Journal of Business Ethics, 101(1), 17-31.

Barnett, C., \& Land, D. (2007). Geographies of generosity: Beyond the "moral turn". Geoforum, 38, 1065-1075.

Bekkers, R., \& Wiepking, (2011). Testing mechanisms for philanthropic behaviour. International Journal of Nonprofit and Voluntary Sector Marketing, 16, 291-297.

Besser, T. L., Miller, N., \& Perkins, R. K. (2006). For the greater good: Business networks and business social responsibility to communities. Entrepreneurship and Regional Development, 18(4), 321-339.

Brammer, S., Millington, A., \& Pavelin, S. (2006). Is philanthropy strategic? An analysis of the management of charitable giving in large UK companies. Business Ethics: A European Review, 15(3), 234-245.

Braun, V., \& Clarke, V. (2006). Using thematic analysis in psychology. Qualitative Research in Psychology, 3(2), 77-101.

Briedenhann, J. (2011). The potential of small tour operators in the promotion of pro-poor tourism. Journal of Hospitality Marketing and Management, 20, 484-500.

Bryman, A. (2008). Social research methods (3rd ed.). Oxford: Oxford University Press.

Buchholtz, A. K., Amason, A. C., \& Rutherford, M. A. (1999). Beyond resources: The mediating effect of top management discretion and values on corporate philanthropy. Business and Society, 38(2), 167-187.

Carroll, A. B. (1991). The pyramid of corporate social responsibility: Toward the moral managment of organizational stakeholders. Business Horizons, 34(4), 39-48.

Carroll, A. B., \& Shabana, K. M. (2010). The business case for corporate social responsibility: A review of concepts, research and practice. International Journal of Management Reviews, 12(1), 85-105.

Chin, M. K., Hambrick, D. C., \& Trevino, L. K. (2013). Political ideologies of CEOs: The influence of executives' values on corporate social responsibility. Administrative Science Quarterly, 58(2), 197-232.

Clegg, S., Kornberger, M., \& Rhodes, C. (2007a). Business ethics as practice. British Journal of Management, 18(2), 107-122.

Clegg, S., Kornberger, M., \& Rhodes, C. (2007b). Organizational ethics, decision making, undecidability. The Sociological Review, 55(2), 393-409.

Coffey, A. (1999). The ethnographic self: Fieldwork and the representation of identity. London: Sage. 
Coles, R., Fenclova, E., \& Dinan, C. (2013). Tourism and corporate social responsibility: A critical review and research agenda. Tourism Management Perspective, 6, 122-141.

Dane, E., \& Pratt, M. G. (2007). Exploring intuition and its role in managerial decision-making. Academy of Management Review, 32(1), 33-54.

Dirks, K. T., \& Ferrin, R. L. (2002). Trust in leadership: Metaanalytic findings and implications for research and practice. Journal of Applied Psychology, 87(4), 611-628.

Donaldson, T., \& Preston, L. E. (1995). The stakeholder theory of the corporation: concepts, evidence and implications. Academy of Management Review, 20(1), 65-91.

Du, S., Swaen, V., Lindgreen, A., \& Sen, S. (2013). The roles of leadership styles in corporate social responsibility. Journal of Business Ethics, 114(1), 155-169.

Duarte, F. (2010). Working with corporate social responsibility in Brazilian companies: The role of managers' values in the maintenance of CSR cultures. Journal of Business Ethics, 96(3), 355-368.

Edwards, M. G., \& Kirkham, N. (2014). Situating "Giving Voice to Values": A metatheoretical evaluation of a new approach to business ethics. Journal of Business Ethics, 121(3), 477-495.

Elms, H., Brammer, S., Harris, J. D., \& Phillips, R. A. (2010). New directions in strategic management and business ethics. Business Ethics Quarterly, 20(3), 401-425.

Falkenberg, L., \& Herremans, I. (1995). Ethical behaviours in organizations: Directed by the formal or informal systems? Journal of Business Ethics, 14(2), 133-143.

Fennell, D. A., \& Przeclawski, K. (2003). Generating goodwill in tourism through ethical stakeholder interactions. In S. Singh, D. J. Timothy, \& R. K. Dowling (Eds.), Tourism in destination communities (pp. 135-152). Wallingford: CABI Publishing.

Gautier, A., \& Pache, A.-C. (2015). Research on corporate philanthropy: A review and assessment. Journal of Business Ethics, 126(3), 343-369.

Gavai, A. K. (2010). Business ethics. Mumbai: Himalaya Publishing House.

Godfrey, P. C. (2005). The relationship between corporate philanthropy and shareholder wealth: A risk management perspective. Academy of Management Review, 30(4), 777-798.

Goodwin, H. (2011). Taking responsibility for tourism: Responsible tourism management. Oxford: Goodfellow Publishers.

Greenwood, M., \& Van Van Buren III, H. J. (2010). Trust and stakeholder theory: Trustworthiness in the organisation-stakeholder relationship. Journal of Business Ethics, 95(3), 425-438.

Haidt, J. (2001). The emotional dog and its rational tail: A social intuitionist approach to moral judgment. Psychological Review, 108(4), 814-834.

Hallak, R., Brown, G., \& Lindsay, N. J. (2013). Examining tourism SME owners' place attachment, support for community and business performance: The role of the enlightened self-interest model. Journal of Sustainable Tourism, 21(5), 658-678.

Halme, M., \& Laurila, J. (2009). Philanthropy, integration or innovation? Exploring the financial and societal outcomes of different types of corporate responsibility. Journal of Business Ethics, 84(3), 325-339.

Hambrick, D. C. (2007). Upper echelons theory: An update. Academy of Management Review, 32(2), 334-343.

Hay, C. (2011). Interpreting interpretivism interpreting interpretations: The new hermeneutics of public administration. Public Administration, 89(1), 167-182.

Hemingway, C. A., \& Maclagan, P. W. (2004). Managers' personal values as drivers of corporate social responsibility. Journal of Business Ethics, 50, 33-44.

Hosmer, L. T. (1995). Trust: The connecting link between organizational theory and philosophical ethics. Academy of Management Review, 20(2), 379-403.
Ibarra-Colado, E., Clegg, S. R., Rhodes, C., \& Kornberger, M. (2006). The ethics of managerial subjectivity. Journal of Business Ethics, 64(1), 45-55.

Ismail, M. (2009). Corporate social responsibility and its role in community development: An international perspective. The Journal of International Social Research, 2(9), 199-209.

Jamal, T., \& Menzel, C. (2009). Good actions in tourism. In J. Tribe (Ed.), Philosophical issues in tourism (pp. 227-243). Bristol: Channel View Publications.

King, N., \& Horrocks, C. (2010). Interviews in qualitative research. London: Sage Publications.

Kramer, R. M. (2006). Trust as situated cognition: An ecological perspective on trust decisions. In R. Bachmann \& A. Zaheer (Eds.), Handbook of trust research (pp. 68-84). Northampton: Edwards Elgar Publishing Inc.

Le, S., Fuller, B., Muriithi, S., Walters, B., \& Kroll, M. J. (2015). The influence of top managers' values on corporate social performance: A meta-analysis. Journal of Managerial Issues, 27(1-4), 9-27.

Lee, H., Park, T., Moon, H. K., Yang, Y., \& Kim, C. (2009). Corporate philanthropy, attitude towards corporations, and purchase intentions: A South Korea study. Journal of Business Research, 62(10), 939-946.

Loacker, B., \& Muhr, S. L. (2009). How can i become a responsible subject? Towards a practice-based ethics of responsiveness. Journal of Business Ethics, 90(2), 265-277.

Longhurst, R. (2010). Semi-structured interviews and focus groups. In N. Clifford, S. French, \& G. Valentine (Eds.), Key methods in geography (2nd ed. ed., pp. 103-115). Thousand Oaks: Sage.

Lorimer, J. (2007). Nonhuman Charisma. Environment and Planning D: Society and Space, 25(5), 911-932.

Love, T., \& Higgins, C. (2007). Turning point: Do we know enough about corporate philanthropy? Journal of Corporate Citizenship, 27, $18-21$.

Luhmann, N. (1979). Trust and power. Chichester: Wiley.

Maak, T., \& Pless, N. M. (2006). Responsible leadership in a stakeholder Society-a relational perspective. Journal of Business Ethics, 66, 99-115.

Maas, K., \& Liket, K. (2011). Talk the walk: Measuring the impact of strategic philanthropy. Journal of Business Ethics, 100(3), 445-464.

Mayer, R. C., Davis, J. H., \& Schoorman, F. D. (1995). An integrative model of organizational trust. Academy of Management Review, 20(3), 709-734.

Mitchell, R. K., Agle, B. R., \& Wood, D. J. (1997). Toward a theory of stakeholder identification and salience: Defining the principle of who and what really counts. Academy of Management Review, 22(4), 853-886.

Moscardo, G. (2014). Social capital, trust and tourism development. In R. Nunkoo \& S. L. J. Smith (Eds.), Trust, tourism development and planning (pp. 64-85). London: Routledge.

Müller, R., Turner, R., Andersen, E. S., Shao, J., \& Kvalnes, Ø. (2014). Ethics, trust, and governance in temporary organizations. Project Management Journal, 45(4), 39-54.

Nunkoo, R., \& Smith, S. L. J. (2014). Trust, tourism development and planning. In R. Nunkoo \& S. L. J. Smith (Eds.), Trust, tourism development and planning (pp. 1-8). London: Routledge.

Perrini, F., \& Minoja, M. (2008). Strategizing corporate social responsibility: Evidence from an Italian medium-sized, familyowned company. Business Ethics, 17(1), 47-63.

Phillips, R. A., Berman, S., Elms, H., \& Johnson-Cramer, M. (2010). Strategy stakeholders and managerial discretion. Strategic organization, $8(2), 176-183$.

Pirson, M., \& Malhotra, D. (2011). Foundations of organizational trust: What matters to different stakeholders? Organization Science, 22(4), 1087-1104. 
Porter, M. E., \& Kramer, M. R. (2002). The competitive advantage of corporate philanthropy. Harvard Business Review, 80(12), 56-68.

Punch, K. F. (2013). Introduction to social research: Quantitative and qualitative approaches (3rd ed.). London: Sage Publications.

Ribar, D. C., \& Wilhelm, M. O. (2002). Altruistic and joy-of-giving motivations in charitable behavior. Journal of Political Economy, 110, 425-457.

Rousseau, D. M., Sitkin, S. B., Burt, R. S., \& Camerer, C. (1998). Not so different after all: A cross-discipline view of trust. Academy of Management Review, 23(3), 393-404.

Sadler-Smith, E., \& Shefy, E. (2004). The intuitive executive: Understanding and applying "gut feel" in decision-making. Academy of Management Executive, 18(4), 76-91.

Saiia, D. H., Carroll, A. B., \& Buchholtz, A. K. (2003). Philanthropy as strategy: When corporate charity "begins at home". Business and Society, 42(3), 169-201.

Saunders, M., Lewis, P., \& Thornhill, A. (2012). Research methods for business students (6th ed.). Harlow: Prentice Hall.

Schilke, O., \& Cook, K. S. (2013). A cross-level process theory of trust development in interorganizational relationships. Strategic Organization, 11(3), 281-303.

Sonenshein, S. (2007). The role of construction, intuition, and justification in responding to ethical issues at work: The sensemaking-intuition model. Academy of Management Review, 32(4), 1022-1040.

Tenbrunsel, A. E., \& Smith-Crowe, K. (2008). Ethical decision making: Where we've been and where we're going. The Academy of Management Annals, 2(1), 545-607.
Thorne, L., \& Saunders, S. B. (2002). The socio-cultural embeddedness of individuals' ethical reasoning in organizations (crosscultural ethics). Journal of Business Ethics, 35(1), 1-14.

Tucker, H., \& Boonabaana, B. (2012). A critical analysis of tourism, gender and poverty reduction. Journal of Sustainable Tourism, 20(3), 437-455.

Wall, G., \& Norris, J. (2003). Gender and tourism. In C. Cooper (Ed.), Classic reviews in tourism (pp. 235-264). Clevedon: Channel View.

Wang, S., Gao, Y., Hodgkinson, G. P., Rousseau, D. M., \& Flood, P. C. (2015). Opening the black box of CSR decision making: A policy-capturing study of charitable donation decisions in China. Journal of Business Ethics, 128(3), 665-683.

Weaver, G. R., Trevino, L. K., \& Cochran, P. L. (1999). Integrated and decoupled corporate social performance: Management commitments, external pressures, and corporate ethics practices. Academy of Management Journal, 42(5), 539-552.

Weiskopf, R., \& Willmott, H. (2013). Ethics as critical practice: The Pentagon Papers, deciding responsibly, truth-telling, and the unsettling of organizational morality. Organization Studies, 34(4), 469-493.

Wicks, A. C., Berman, S. L., \& Jones, T. M. (1999). The structure of optimal trust: Moral and strategic implications. The Academy of Management Review, 24(1), 99-116.

Wood, D. J. (1991). Corporate social performance revisited. Academy of Management Review, 16(4), 691-718.

Yin, R. K. (2009). Case study research: Design and methods (4th ed.). London: Sage.

Zinn, J. O. (2008). Heading into the unknown: Everyday strategies for managing risk and uncertainty. Health, Risk and Society, 10(5), 439-450. 